\title{
ANALISIS LAPORAN KEUANGAN
}

Makalah Ini Disusun Untuk Memenuhi Tugas Mata Kuliah Kewirausahaan

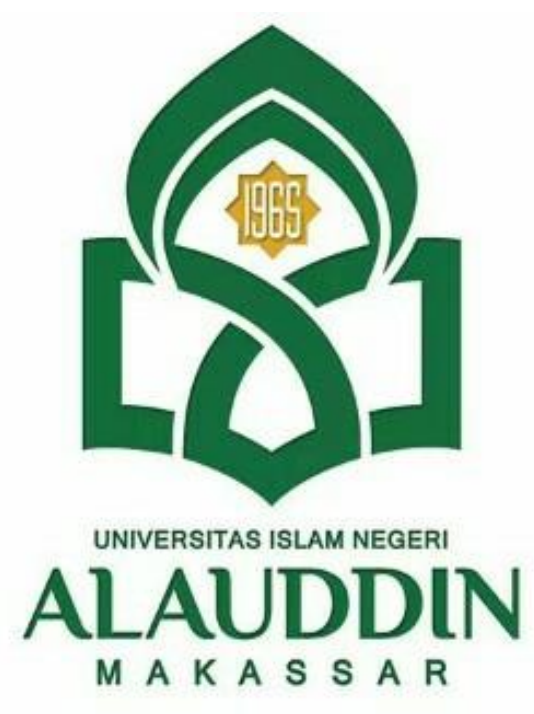

WINDA AULYA

yulandavina60@gmail.com

\author{
PROGRAM STUDI PERBANKAN SYARIAH \\ FAKULTAS EKONOMI DAN BISNIS ISLAM \\ UNIVERSITAS ISLAM NEGERI ALAUDDIN MAKASSAR
}

2021 


\section{KATA PENGANTAR}

Puji syukur kehadirat Allah SWT yang telah memberikan rahmat dan hidayatNya sehingga penulis dapat menyelesaikan tugas makalah ini yang berjudul "Mengelola Sumber Daya Manusia” ini dengan tepat waktu.

Makalah ini ditulis dengan tujuan untuk memenuhi tugas pada mata kuliah Kewirausahaan. Selain itu, makalah ini bertujuan untuk menambah wawasan tentang bagaimana cara menganalisis laporan keuangan bagi para pembaca dan juga penulis.

Penulis juga mengucapkan terima kasih kepada Ibu Dra. Hj. NuraeniGani, MM. Selaku dosen yang telah memberikan tugas ini sehingga dapat menambah pengetahuan dan wawasan sesuai bidang yang kami tekuni.

Makalah yang kami tulis ini masih jauh dari kata sempurna. Oleh karena itu, penulis mengharapkan kritik dan saran yang membangun demi kesempurnaan makalah ini.

Gowa, 21 Desember 2021

ANDI RESVINA YULANDA 


\section{DAFTAR ISI}

ANALISIS LAPORAN KEUANGAN ............................................................... $\mathrm{i}$

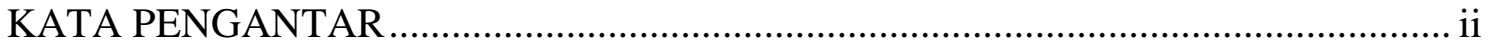

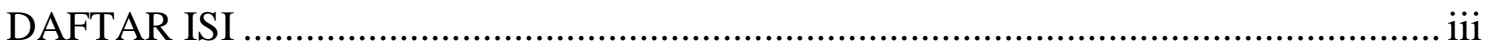

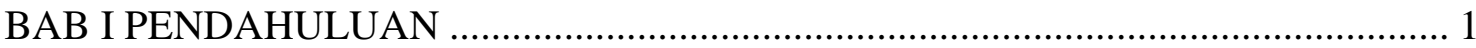

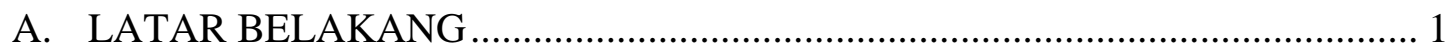

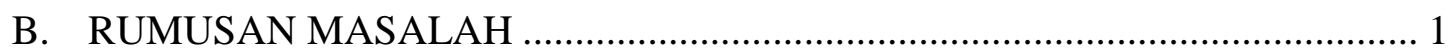

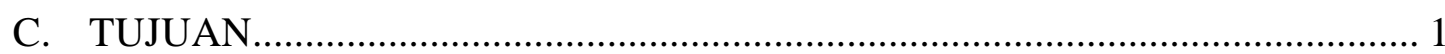

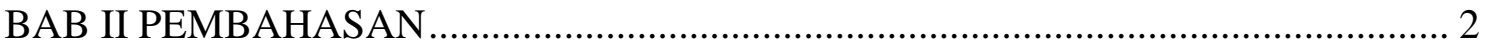

A. PENGERTIAN ANALISIS LAPORAN KEUANGAN .................................... 2

B. TUJUAN ANALISIS LAPORAN KEUANGAN ................................................ 2

C. RASIO LAPORAN KEUANGAN............................................................... 4

1. Pengertian Rasio Laporan Keuangan ........................................................ 4

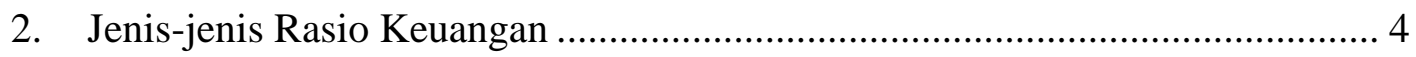

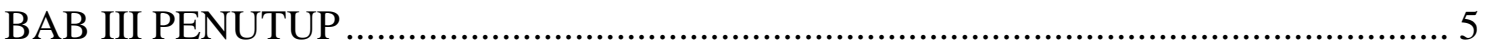

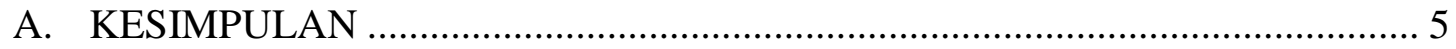

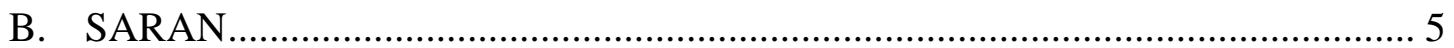




\section{BAB I \\ PENDAHULUAN}

\section{A. LATAR BELAKANG}

Analisis rasio keuangan merupakan suatu alat analisa yang dipakai oleh perusahaan untuk menilai dan menganalisis kinerja keuangan berdasarkan data perbandingan masing-masing pos yang terdapat di dalam laporan keuangan contohnya laporan Laba rugi, Neraca, dan Arus kas dalam kurun waktu tertentu. Setiap tutup periode akhir bulan, biasanya accounting perusahaan menyiapkan dan menyusun laporan keuangan yang terdiri dari laporan neraca, rugi laba, arus kas, perubahan modal, dan laporan tersebut nantinya akan diserahkan kepada pimpinan perusahaan.

Tujuan laporan keuangan adalah untuk memberikan sebuah gambaran dan penjelasan informasi mengenai posisi keuangan dan kinerja perusahaan yang dapat dijadikan pedoman dalam mengambil keputusan bisnis. Analisis data laporan keuangan dilakukan dengan menganalisa masing-masing pos yang terdapat di dalam laporan keuangan dalam bentuk rasio posisi keuangan dengan tujuan agar dapat memaksimalkan kinerja perusahan untuk masa yang akan datang Perkembangan dunia usaha mengalami pertumbuhan yang pesat, hal ini menyebabkan persaingan antar perusahaan semakin kompetitif.

Pertumbuhan dunia usaha yang pesat dikarenakan oleh berbagai faktor, salah satu contoh faktor yang mempengaruhi yaitu faktor teknologi yang dari zaman ke zaman terus berkembang semakin canggih. Perusahaan menyadari munculnya berbagai tantangan yang harus dihadapi, baik perusahaan sejenis di dalam negeri maupun yang berasal dari luar negeri.

\section{B. RUMUSAN MASALAH}

1. Apa pengertian analisis laporan keuangan?

2. Apa tujuan analisis laporan keuangan?

3. Apa itu rasio laporan keuangan?

\section{TUJUAN}

1. Untuk mengetahui pengertian analisis laporan keuangan

2. Untuk mengetahui tujuan analisis laporan keuangan

3. Untuk mengetahui rasio laporan keuangan 


\section{BAB II \\ PEMBAHASAN}

\section{A. PENGERTIAN ANALISIS LAPORAN KEUANGAN}

Secara umum, analisis laporan keuangan adalah sebuah proses mengamati performa perusahaan dalam konteks lingkungan industri dan ekonomi dengan tujuan pengambilan keputusan tertentu. Biasanya, keputusan yang akan dibuat berkaitan dengan penyediaan modal bagi perusahaan, terutama investor yang ingin menanamkan modal atau lembaga pemberi pinjaman. Secara umum, fokus dari analisis laporan keuangan adalah evaluasi terhadap kemampuan perusahaan untuk mendapatkan keuntungan setidaknya sejumlah modal yang dimiliki, menjalankan kegiatan yang profitable, dan mampu menghasilkan uang untuk memenuhi kewajiban perusahaan dan mengejar kesempatan yang lebih baik.

Selain memahami konsep umum dari analisis laporan keuangan, ada baiknya kamu juga mengetahui pengertian analisis laporan keuangan menurut para ahli di bidang ekonomi.

Dalam buku The Analysis and Use of Financial Statements, Gerald White mendefinisikan analisis laporan keuangan sebagai sebuah metode atau proses yang meliputi teknik khusus untuk mengevaluasi risiko, performa, kesehatan finansial, dan prospek masa depan sebuah perusahaan.

Richard W. Metcalf dan Pierre L. Titard dalam Principle of Accounting menjelaskan analisis laporan keuangan sebagai proses evaluasi hubungan antara komponen-komponen laporan keuangan untuk mendapatkan pemahaman yang lebih baik tentang posisi dan performa sebuah lembaga.

Sementara itu, dalam bukunya yang berjudul Financial Statement Analysis, John Nicholas Myer menyebut analisis laporan keuangan sebagai sebuah studi besar mengenai hubungan antara berbagai faktor finansial dalam sebuah bisnis seperti yang tercantum dalam sebuah laporan.

\section{B. TUJUAN ANALISIS LAPORAN KEUANGAN}

Laporan keuangan bisa saja menyembunyikan suatu informasi yang salah, tetapi hasil dari analisis laporan keuangan tidak dapat menyembunyikan semua 
informasi yang salah. Hasil analisis laporan keuangan akan memperlihatkan segala yang salah dalam laporan keuangan, yaitu :

1. Kesalahan dalam proses akuntansi, seperti kesalahan pencatatan, kesalahan jumlah, kesalahan pembukuan, kesalahan perkiraan, kesalahan posting dan kesalahan dalam menjurnal.

2. Kesalahan yang sengaja, seperti tidak mencatat harga dengan wajar, penghilangan data, dll.

Jadi analisis laporan keuangan pada dasarnya untuk menambah informasi yang ada dalam suatu laporan keuangan perusahaan. Adapun kegunaan dari analisis laporan keuangan adalah :

1. Memberikan informasi yang lebih luas dan mendetail dibandingkan dengan hanya laporan keuangan saja.

2. Memberikan informasi kesalahan yang terkandung dalam laporan keuangan.

3. Dapat menunjukkan hal-hal yang tidak konsisten dalam penyajian laporan keuangan.

4. Dapat memberikan informasi yang berguna bagi pengambil keputusan (decision maker) di suatu perusahaan.

5. Menunjukkan peringkat perusahaan dalam kriteria tertentu di dunia bisnis.

6. Dapat digunakan untuk membandingkan suatu perusahaan dengan perusahaan lain.

7. Memberikan informasi keadaan perusahaan pada saat ini.

8. Sebagai dasar untuk memprediksi keadaan perusahaan dimasa yang akan datang.

9. Sebagai dasar informasi perusahaan untuk mengambil tindakan investasi, merger atau akuisisi perusahaan.

10. Untuk menilai prestasi manajemen,operasional dan efisiensi perusahaan.

Dengan melihat analisis laporan keuangan, maka informasi yang mentah disajikan pada laporan keuangan akan terlihat atau terbaca lebih jelas, dalam dan lebih terperinci. 


\section{RASIO LAPORAN KEUANGAN}

\section{Pengertian Rasio Laporan Keuangan}

Ratio keuangan atau rasio keuangan atau rasio finansial merupakan suatu alat dalam menganalisa dan mengukur kinerja perusahaan dengan menggunakan parameter kondisi atau data keuangan perusahaan tersebut. Data-data keuangan tersebut biasanya diambil dari laporan keuangan yang ada seperti neraca, laporan laba rugi, laporan arus kas, dll.

\section{Jenis-jenis Rasio Keuangan}

Berdasarkan fungsi atau penggunaannya, rasio keuangan kemudian dibagi menjadi beberapa jenis. Oleh karena itu, secara umum ratio keuangan dibagi menjadi 4 (empat) jenis. Berikut detail penjelasan terkait jenis-jenis rasio keuangan, yaitu:

- Ratio Profitabilitas (Profitability Ratio)

Ratio profitabilitas digunakan untuk mengukur kemampuan perusahaan dalam menghasilkan keuntungan untuk perusahaan. Rasio profitabilitas dianggap memiliki peranan yang krusial bagi kelangsungan perusahaan karena "urat nadi" suatu perusahaan akan bergantung dari sejauh mana perusahaan bisa mendapatkan keuntungan.

- Ratio Likuiditas (Liquidity Ratio)

Ratio likuiditas digunakan untuk mengukur kemampuan perusahaan dalam membayar atau melunasi utang atau kewajiban dalam skala jangka pendek yang harus segera dipenuhi.

- Ratio Solvabilitas (Solvency Ratio)

Ratio solvabilitas digunakan untuk mengukur kemampuan perusahaan dalam melunasi semua kewajibannya, baik kewajiban jangka panjang maupun jangka pendek, utamanya apabila disaat perusahaan yang bersangkutan harus dilikuidasi.

- Ratio Aktivitas (Activity Ratio)

Rasio aktivitas digunakan untuk mengukur keefektifan atau efisiensi perusahaan dalam menggunakan aktiva - aktiva yang dimilikinya. 


\section{BAB III \\ PENUTUP}

\section{A. KESIMPULAN}

Analisis laporan keuangan adalah sebuah proses mengamati performa perusahaan dalam konteks lingkungan industri dan ekonomi dengan tujuan pengambilan keputusan tertentu. Biasanya, keputusan yang akan dibuat berkaitan dengan penyediaan modal bagi perusahaan, terutama investor yang ingin menanamkan modal atau lembaga pemberi pinjaman. Laporan keuangan bisa saja menyembunyikan suatu informasi yang salah, tetapi hasil dari analisis laporan keuangan tidak dapat menyembunyikan semua informasi yang salah.

Ratio keuangan atau rasio keuangan atau rasio finansial merupakan suatu alat dalam menganalisa dan mengukur kinerja perusahaan dengan menggunakan parameter kondisi atau data keuangan perusahaan tersebut.

\section{B. SARAN}

Tentunya terhadap penulis sudah menyadari jika dalam penyusunan makalah di atas masih banyak ada kesalahan serta jauh dari kata sempurna. Adapun nantinya penulis akan segera melakukan perbaikan susunan makalah itu dengan menggunakan pedoman dari beberapa sumber dan kritik yang bisa membangun dari para pembaca. 